\title{
Source Rock Evaluation of the Shale Beds Penetrated by Kinasar-1 Well, Se Bornu Basin, Nigeria
}

\author{
Peter Sunday Ola \\ Department of Applied Geology, The Federal University of Technology, Akure, Nigeria \\ Email: psola@futa.edu.ng
}

How to cite this paper: Ola, P.S. (2018) Source Rock Evaluation of the Shale Beds Penetrated by Kinasar-1 Well, Se Bornu Basin, Nigeria. Open Journal of Geology, 8, 1056-1068.

https://doi.org/10.4236/ojg.2018.811064

Received: April 22, 2018

Accepted: May 3, 2018

Published: October 31, 2018

Copyright $\odot 2018$ by author and Scientific Research Publishing Inc. This work is licensed under the Creative Commons Attribution International License (CC BY 4.0).

http://creativecommons.org/licenses/by/4.0/

\section{cc) (i) Open Access}

\begin{abstract}
This paper investigates the hydrocarbon generation potential of the shale beds penetrated by Kinasar-1 well in the SE depression of the Bornu Basin, Nigeria. The objective of the study was to select shale sample from the ditch cuttings of the well and assess their source rock status based on the integration of four routinely used indicators: TOC, HI, Tmax, and VR. While all the strata analysed contain sufficient organic matter (TOC > 0.5) for hydrocarbon generation, the $\mathrm{HI} / \mathrm{T}_{\max }$ plot suggests slightly matured to matured type II/III kerogen that is capable of generating only gas as revealed by the HI/TOC plot. Of tectonic significance is the Vitrinite reflectance result, which suggests cooling, based on observed VR reversal at depth. This is interpreted herein as marking a period of uplift and erosion that is totally different from and occurred before the intra-Maastrichtian unconformity that affected all the basins of WACRS.
\end{abstract}

\section{Keywords}

Bornu Basin, Gas, Kinasar, Source Rock, Unconformity

\section{Introduction}

Evaluation of hydrocarbon generation potential of the Bornu Basin (Figure 1) is critical now that there is renew and more desperate interest in the search for hydrocarbon in the basin, considering the amount of futile efforts already put into it. Twenty three exploratory wells (Figure 1) have been drilled without any discovery in spite of major discoveries in its contiguous basins in the Chad and Niger territories. Encouraged by similar persistent efforts that eventually led to oil discovery in some other intercontinental basins in Africa, the Federal Govern- 
ment of Nigeria holds the opinion that commercial hydrocarbon deposit could be found in the basin.

Every oil or gas play originates from source rock and the viability of each play-conventional or unconventional, oil or gas-depends on it [1]. Source rock evaluation studies entail assessing the hydrocarbon generating potential of sediments by looking at the sediment's capacity for hydrocarbon generation, type of organic matter (kerogen) present and what hydrocarbons might be expected after generation, and the sediment's thermal maturity and how it has influenced generation [2] [3]. Various tools, techniques and indices for source rock evaluation are readily available and well documented in the literature [1] [4] [5] [6].

Extensive source rock assessments in the Bornu Basin have been carried out [7] [8] [9] [10] [11]. Based on these studies, source rock availability in the Bornu Basin was reviewed by Adekoya et al. [12]. More recent works include [13]. A fair knowledge of the hydrocarbon potential of the basin is known. Notwithstanding a more detailed study is still desirable, particularly studies that focus on individual exploration well in relation to each of the three depressions [14] in the basin. Beds within each of the sags are to a large extent correlatable [14] suggesting a genetic relationship that could permit interpolation of results all over a sag area.

The aim of this work therefore is to ascertain source rock availability and quality within the strata penetrated by Kinasar- 1 well with a view to relating the result to existing results within sag $\mathrm{C}$ in the Maiduguri SE portion of the basin, and other producing basins in like the Termit and Agadem and Tenere blocks of the Mega Chad Basin. The significance of Kinasar-1 well to source rock evaluation

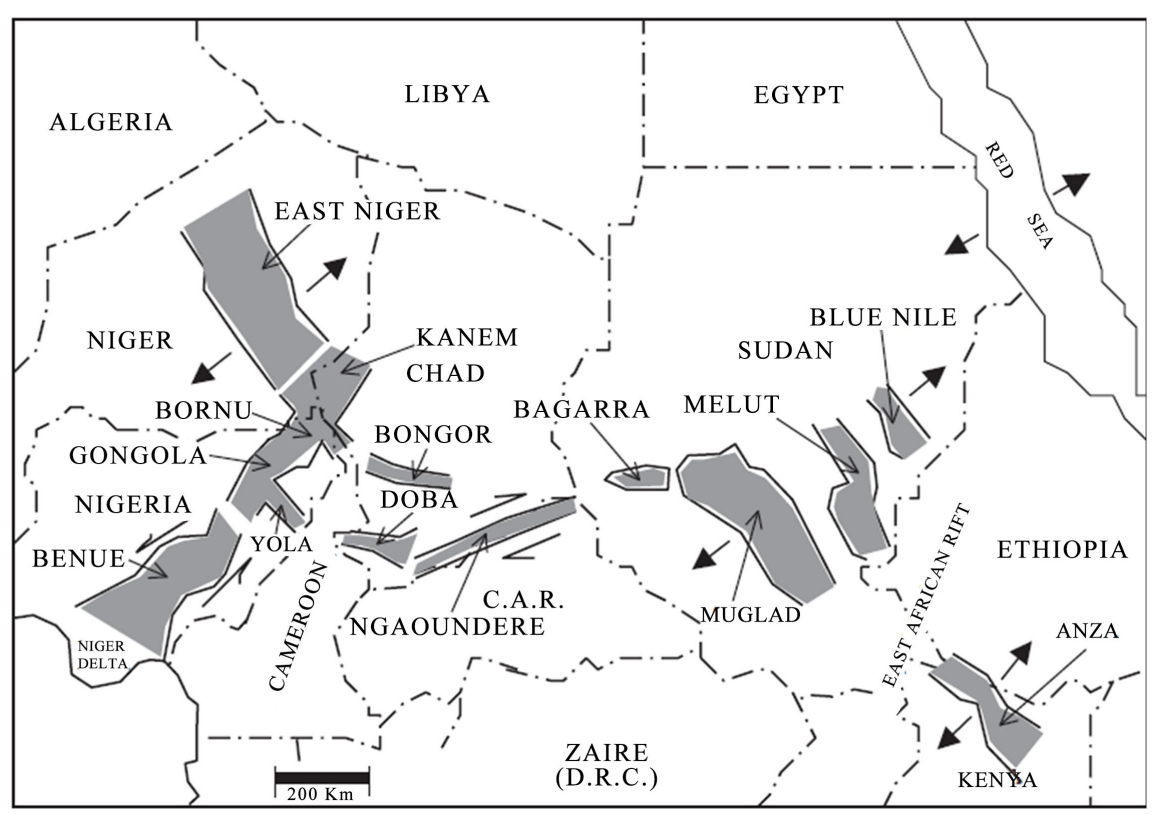

Figure 1. Regional tectonic map of western and central african rifted basins showing the relationship of the bornu basin to some other interior basins of africa (Schull, 1988; Obaje, 2004). 
in the Bornu Basin is twofold: firstly, it is one of the two wells where insignificant gas is documented and secondly it is the deepest well drilled so far in the basin [15]. The source rock evaluation is however limited to selected shales' samples of the Fika Formation that shows potential for hydrocarbon generation. The optimism driving the research is that efforts leading to discovery of hydrocarbon in frontier basins require decades of intensive research and exploration. For example hydrocarbon was not discovered in the Niger Delta until about fifty years of exploration beginning from 1908 to 1957 when the oil was discovered in Oloibiri.

\section{Geological Setting}

The Bornu Basin is one of the basins within the Mega Chad Basin, an inland rift basin which is part of the West and Central African Rift System (Figure 1). The geodynamic evolution of the West and Central African Rift System (WCARS) is linked to the development of the African plate throughout the Phanerozoic and is related to the polyphase break-up of the Gondwana supercontinent [16] [17] [18] [19]. The WCARS has been subdivided into two coeval Cretaceous genetically related but physically separated rift subsystems, which are the West African Rift Subsystem (WAS-Benue Trough, Yola/Garouna rift, Gongola/Bornu rift, Niger/Chad) and Central African Rift Subsystem (CAS-Doba, Doseo, Salamat). The geotectonic history of the WAS and CAS was divided into two pre-drift, two Cretaceous rift, one Paleogene rift and one post-rift phases. The Chad Basin straddles five countries, namely, Nigeria, Niger, Chad Republic, Cameroon and Central Africa Republic. Approximately one-tenth of its surface area constitutes the Bornu Basin.

\section{Stratigraphy}

The general geology of the Bornu Basin has received considerable attention [20]-[27] because of the intense search for hydrocarbon there. Its stratigraphic sequences have been extensively discussed and established [22] [25] [27] [28] [29] [30] to be related to that of the Benue Trough that has received considerable study and appear better understood (Figure 2). The principal stratigraphic units in the basin are: the Bima, Yolde/Gongila, Fika, Gombe, Kerri-Kerri and Chad Formations.

The Bima Formation unconformably overlies the Precambrian basement and is considered to be generally composed of feldspathic, coarse grained sandstones with beds of quartz pebbles and some layers of shale. These sediments are mainly continental and vary in age from Neocomian to Cenomanian [31]. A widespread Cenomanian-Turorian marine transgression into the Chad basin led to the deposition of the Gongila and Fika Formations [32] [33]. Gongila Formation comprises shales and fossiliferous limestone, which marks the boundary with the underlying Bima Formation. It is important to note that in the upper Benue Trough, the Yolde Formation lies in between the Bima and Gongila Formations, which suggests the need to clarify its existence in the Bornu Basin. The 
Fika Formation is made up of blue-grey shales, with irregular limestone layers. Coniacian to Santonian age has been assigned to this formation. Overlying the Fika shale is the Gombe Formation. From outcrop and shallow borehole studies the formation consists of rare basal conglomerate, grit, sandstone and clay [33]. While Avbovbo [25] recognized coal beds as part of the Gombe Formation, Moumouni et al. [10] did not include the formation in the interpreted stratigraphy of some wells (Kanadi-1, Albarka-1, Gaibu-1 and Kasade-1).

Between Gombe and the overlying Kerri-Kerri Formation an unconformity was observed [8] [12] [33] marking the Cretaceous/Tertiary boundary. The Kerri-Kerri Formation consists mainly of fine to coarse grained ferruginous sandstones, siltstones, clays, clayey sandstones and laterite (oolitic and vesicular). The Kerri-Kerri and Chad Formations overlie the Cretaceous Formations and constitute the Tertiary sediments of the Chad Basi [29].

\section{Methodology}

Following a detailed sedimentological studies (result of which is not reported herein) of cuttings of Kinasar-1 well, nine samples were selected from the strata penetrated by the well, which is situated in the south-eastern portion of the Bornu Basin (Figure 3). The samples were sieve-washed under running water to remove drilling contaminants, dried and pulverized. The grounded samples were pre-treated to remove inorganic carbon, first with $10 \%$ hydrochloric Acid $(\mathrm{HCl})$ and then with $30 \% \mathrm{HCl}$. The resulting "carbonate" free sample was analysed in the CS244 analyser to determine its total organic carbon (TOC). The TOC values were obtained in weight percent ( $w t \%)$ of the original rock.

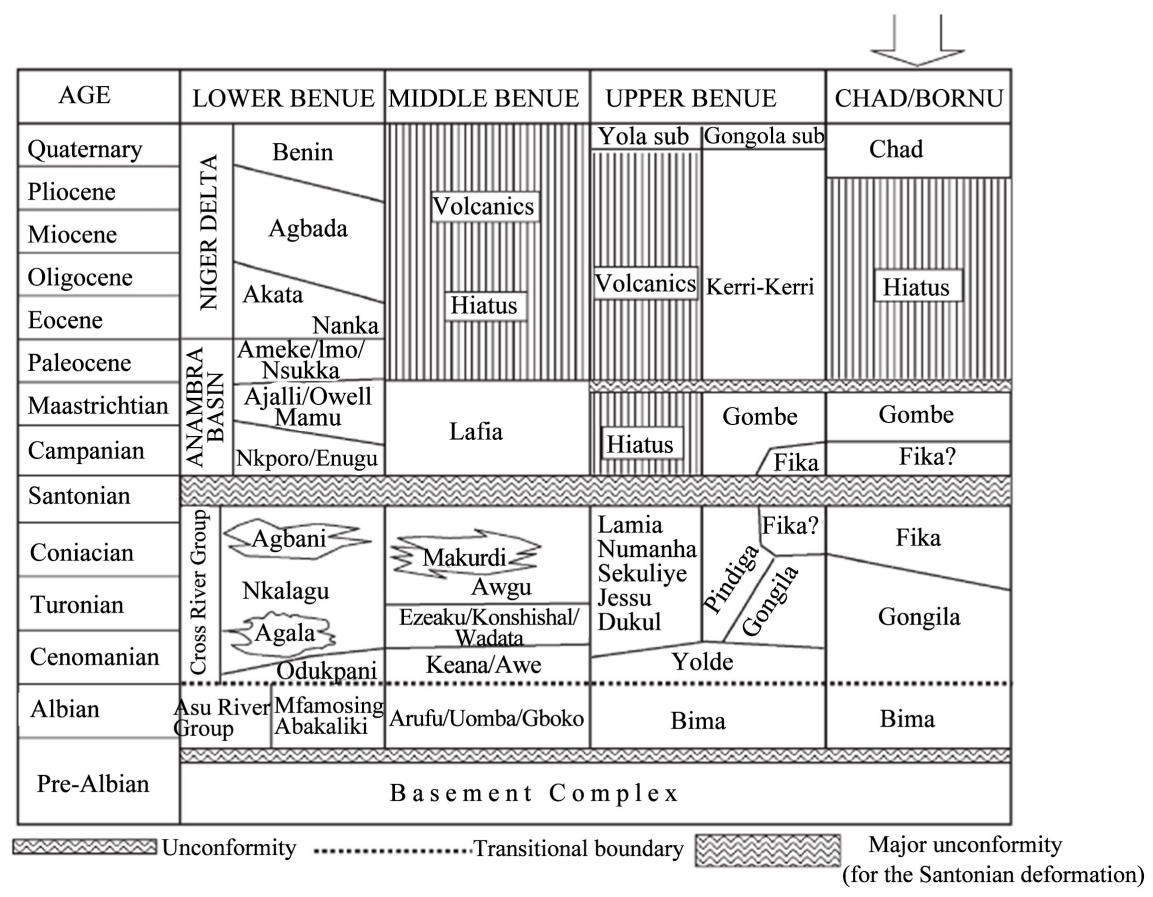

Figure 2. Stratigraphic successions in the bornu basin and its contiguous benue trough (Obaje, 2004). 


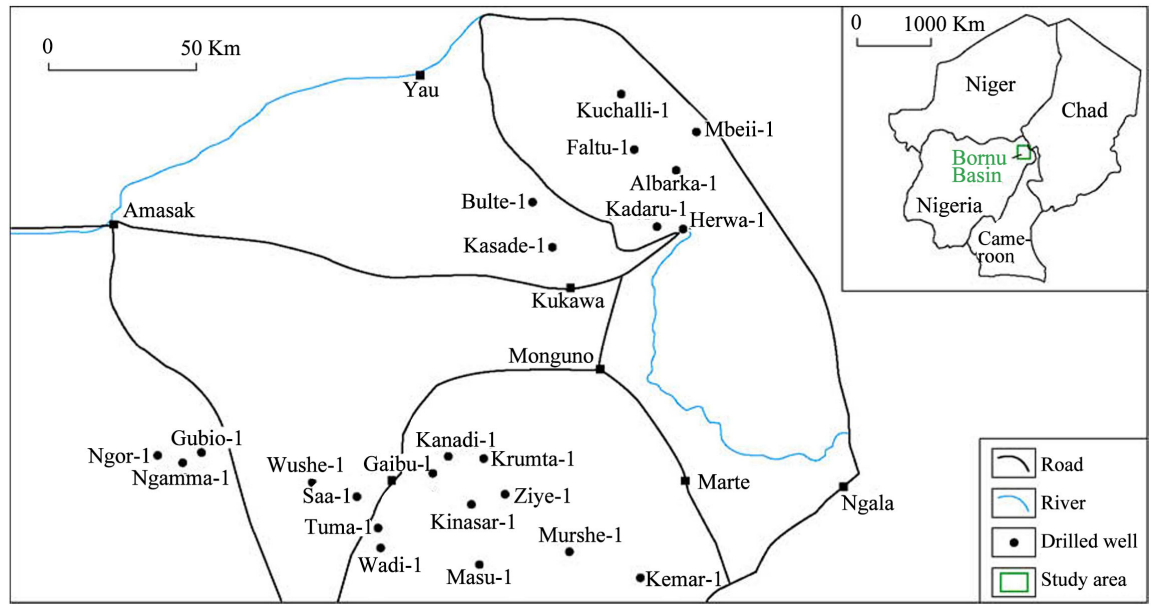

Figure 3. Location of the Bornu Basin showing the location of drilled wells in the basin and three areas of thick sedimentary deposits in the basin. The focus of study is depression D. Inset Position of the basin in relation to Nigeria, Chad and Niger (Modified after Olabode et al., 2015).

Rock-Eval pyrolysis was performed on each of the samples utilizing $100 \mathrm{mg}$ of powdered whole rock and using a GEO-IMT-2005 instrument. The pyrolysis parameters obtained were the $\mathrm{S} 1$ peak (mg of pre-existing hydrocarbon per gram of rock), the S2 peak (mg of hydrocarbons per gram of rock, derived from thermal breakdown of the kerogen), the $\mathrm{S} 3$ peak (amount of $\mathrm{CO}_{2}$-in $\mathrm{mg} \mathrm{CO}$ per $\mathrm{g}$ of rock produced during pyrolysis of kerogen), and the Tmax (temperature in ${ }^{\circ} \mathrm{C}$ corresponding to maximum hydrocarbon generation). Other parameters derived from the foregoing data include the hydrogen index $(\mathrm{HI})$, the production index (PI) and oxygen index (OI). The HI is S2 normalised to the TOC of the sample $(\mathrm{mgHC} / \mathrm{g}$ TOC) and is indicative of unoxidised hydrogen in the system. The PI is indicative of thermal maturity and the hydrocarbon generation capability of the source rock, which is determined by $\mathrm{S} 1 /(\mathrm{S} 1+\mathrm{S} 2)$. The OI is indicative of gas richness and is determined by $\mathrm{S} 3 /(\mathrm{S} 1+\mathrm{S} 2)[1]$.

\section{Result}

\subsection{Bulk Geochemistry}

The TOC values of the samples except one generally vary from $0.60 \%$ to $1.63 \%$ (Table 1). The exception, obtained at a depth of $1670-1675 \mathrm{~m}$, yielded an anomalous organic-rich facies with a TOC value of $2.30 \%$. Eight of the samples have HI values between 50 and $100 \mathrm{mgHC} / \mathrm{g}$ TOC. This HI values are typical of Type III kerogen. Only one sample retrieved at a depth of $1670-1675 \mathrm{~m}$ has value below $60 \mathrm{mgHC} / \mathrm{g}$ TOC. Seven of the nine samples analysed for $\mathrm{T}_{\text {max }}$ have values between $435^{\circ} \mathrm{C}$ and $452^{\circ} \mathrm{C}$ (Figure 4) suggesting thermally mature sediments. A slightly low $\mathrm{T}_{\max }$ value of $432^{\circ} \mathrm{C}$ was obtained at a depth of $2140-2145 \mathrm{~m}$. A sample analysed at a depth of $2280-2285 \mathrm{~m}$ is postmature (gas window) having $\mathrm{T}_{\max }$ value of $488^{\circ} \mathrm{C}$. This result is clearly displayed in Figure 5. On the HI/Tmax plot (Figure 5) the majority of the samples cluster at the centre of Type II/Type III 
Table 1. Pyrolysis results of selected shale cuttings from Kinasar-1 well, Bornu Basin, Nigeria.

\begin{tabular}{|c|c|c|c|c|c|c|c|c|c|c|c|c|c|}
\hline \multicolumn{14}{|l|}{ Kinasar-1 } \\
\hline $\begin{array}{c}\text { Age (Adekoya } \\
\text { et al. 2014) }\end{array}$ & Formation & Lithology & $\begin{array}{l}\text { Depth } \\
(\mathrm{m})\end{array}$ & $\begin{array}{l}\text { TOC } \\
(w t \%)\end{array}$ & $\begin{array}{c}\mathrm{S} 1 \\
\mathrm{mg} / \mathrm{g}\end{array}$ & $\begin{array}{c}\mathrm{S} 2 \\
\mathrm{mg} / \mathrm{g}\end{array}$ & $\begin{array}{c}\mathrm{S} 3 \\
\mathrm{mg} / \mathrm{g}\end{array}$ & $\begin{array}{l}\mathrm{HI}=\mathrm{S} 2 / \\
(\mathrm{S} 1+\mathrm{S} 2)\end{array}$ & $\begin{array}{l}\mathrm{OI}=\mathrm{S} 3 / \\
(\mathrm{S} 1+\mathrm{S} 2)\end{array}$ & $\begin{array}{l}\mathrm{PI}=\mathrm{S} 1 / \\
(\mathrm{S} 1+\mathrm{S} 2)\end{array}$ & $\mathrm{T}_{\max }$ & $\mathrm{S} 2 / \mathrm{S} 3$ & $\begin{array}{l}\text { S1/TOC } \\
100\end{array}$ \\
\hline Coniacian & & Shale & $1090-1095$ & 0.71 & 0.54 & 0.80 & 0.76 & 113 & 107 & 0.40 & 438 & 1.05 & 76.06 \\
\hline Coniacian & & Shale & $1290-1295$ & 0.82 & 0.44 & 0.67 & 0.44 & 82 & 54 & 0.40 & 436 & 1.52 & 53.66 \\
\hline Coniacian & & Shale & $1410-1415$ & 0.83 & 0.45 & 0.53 & 0.71 & 64 & 86 & 0.46 & 435 & 0.75 & 54.22 \\
\hline Turonian & & Shale & $1670-1675$ & 2.30 & 0.58 & 0.75 & 0.61 & 33 & 27 & 0.44 & 441 & 1.23 & 25.22 \\
\hline Turonian & FIKA & Shale & $1770-1775$ & 0.60 & 0.33 & 0.57 & 0.60 & 95 & 100 & 0.36 & 436 & 0.95 & 55.00 \\
\hline Turonian & & Shale & $2140-2145$ & 0.71 & 0.29 & 0.89 & 0.67 & 125 & 94 & 0.25 & 432 & 1.33 & 40.85 \\
\hline Turonian & & Shale & $2180-2185$ & 1.63 & 0.43 & 2.19 & 0.45 & 134 & 28 & 0.16 & 452 & 4.87 & 26.38 \\
\hline Turonian & & Shale & $2220-2225$ & 0.66 & 0.30 & 0.77 & 0.54 & 117 & 82 & 0.28 & 446 & 1.43 & 45.45 \\
\hline Turonian & & Shale & $2280-2285$ & 1.83 & 0.50 & 2.32 & 0.32 & 127 & 17 & 0.18 & 488 & 7.25 & 27.32 \\
\hline
\end{tabular}

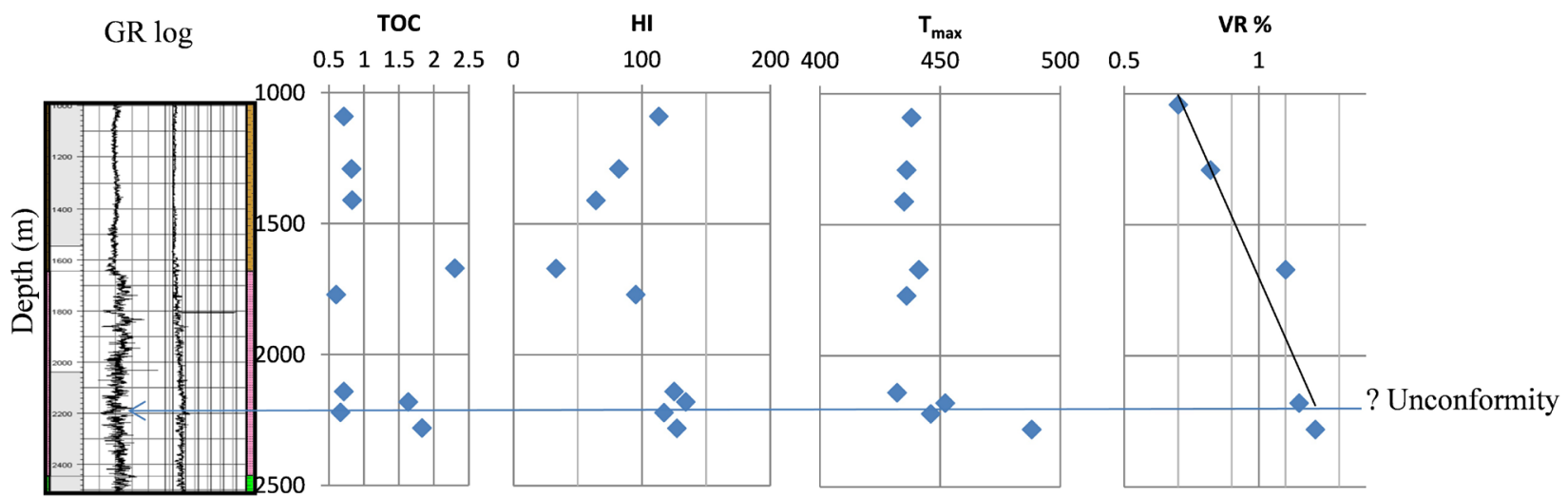

Figure 4. A plot of wire-line log and source rock indices derived from the bulk geochemical data of ditch cutting samples of Fika Shale in Kinasar-1 well, SE Bornu Basin, Nigeria.

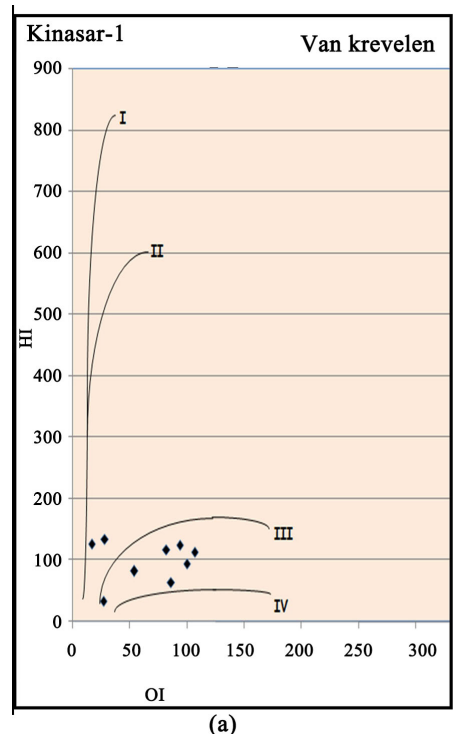

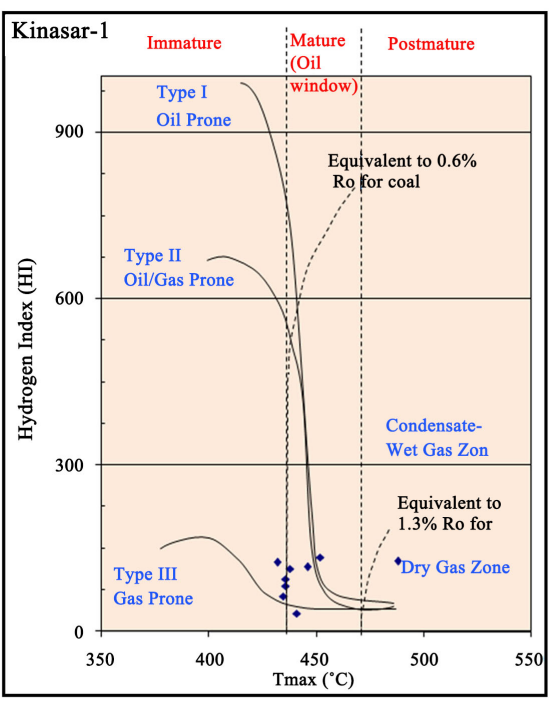

(b)

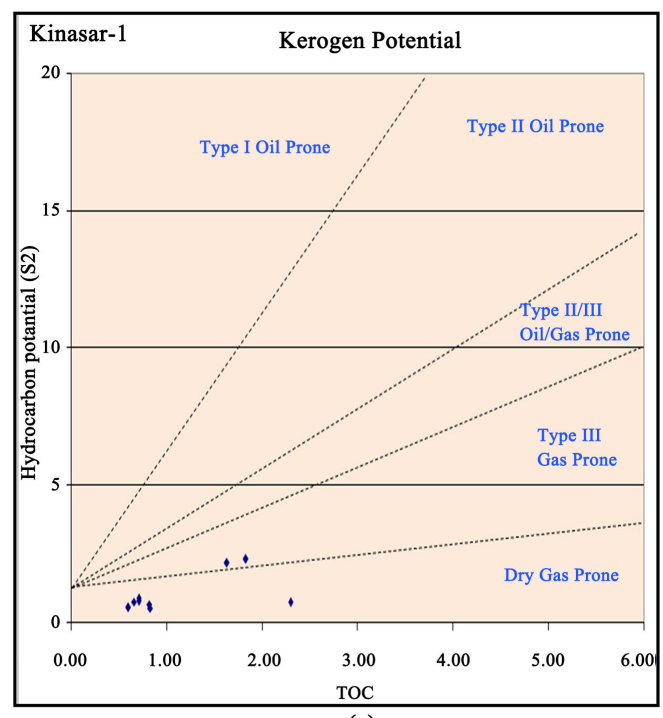

(c)

Figure 5. Source rock evaluation of the strata of Fika Shale as penetrated by Kinasar-1 well, SE Bornu Basin. (a) Type of kerogen plot showing type III/II kerogen; (b) Maturation level of the organic matter; and (c) Hydrocarbon generation potential. 
kerogen while some are at the boundary. Again some of the samples cluster at the point marking the onset of hydrocarbon generation window (Figure 5).

\subsection{Vitrinite Reflectance}

Vitrinite reflectance is a better maturity indicator. Five of the samples selected at depths of $1040 \mathrm{~m}, 1290 \mathrm{~m}, 1670 \mathrm{~m}, 2180 \mathrm{~m}$ and $2280 \mathrm{~m}$ were analysed to determine the level of maturity in the area around the well using this tool. These samples were composed of siltstone and mudstone characterised by variable organic matter content (Figure 6). Siltstone samples had higher organic matter content varying from low to high while mudstone samples exhibited moderate organic matter content. Occasionally, there were one or two fragments of mudstone that were more laminated and had higher concentration of organic matter particles. Siltstone and mudstone samples were dominated by very small particles that were typically recycled vitrinite and inertinite and stringers of coal-like fragments (Figure 6). Primary vitrinite was present in low quantity and was poor and small and often difficult to distinguish from recycled vitrinite. Siltstone was occasionally glauconitic and had very light matrix bitumen stain. Mudstone samples showed moderate to strong matrix bitumen stain. There was a trace quantity of liptinite. Algal cysts fluoresced yellow with moderate intensity. One good quality spore fluoresced mid to dark orange with low intensity. Other tentatively identified algal cysts and spores were yellow orange and light orange, respectively. In some samples no convincing organic matter fluorescence was detected. Cavings were present.

Thermal maturity in the samples varies from peak oil window to early peak oil window and late oil window to early wet gas/condensate zone (Figure 5). The vitrinite reflectance values are as contained in Figure 6(b).

\section{Dicussion}

\subsection{Source Rock Evaluation in the South-Eastern Portion of the Bornu Basin}

The significance of Kinasar-1 well to source rock evaluation in the Bornu Basin is twofold: firstly, it is one of the two wells where insignificant gas are documented and secondly, it is the deepest well drilled so far in the basin [18]. Within the south-eastern portion of the basin, a fairly good wireline log correlation occurs among the existing exploration wells [14] suggesting possible genetically related shale beds within the Fika Formation. In this study, source rock evaluation concentrate on selected shale beds of Fika Formation considered viable as source rock. The section shallower than interval focus in this study contains predominantly clay, sands and clayey sands of Maastrichtian/Tertiary sequences [12].

Based on the $0.5 \mathrm{wt} \%$ as the lowest for hydrocarbon generation, the shale beds of the Fika Formation contain sufficient organic matter to generate hydrocarbon. All the samples had TOC greater than $0.5 \mathrm{wt} \%$. A similar trend has been 


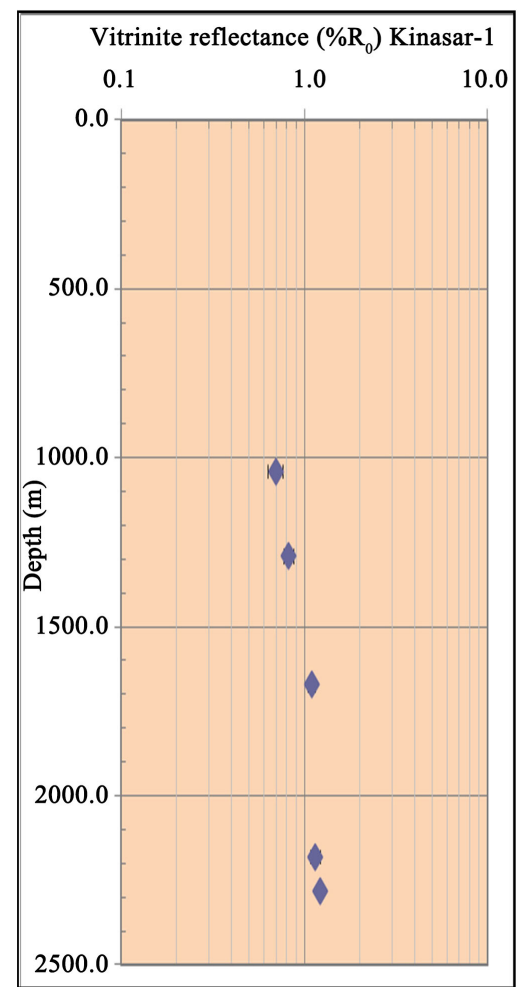

(a)

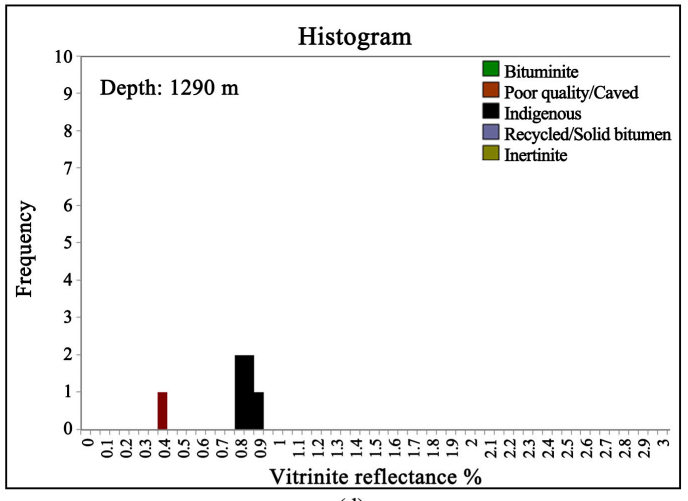

(d)

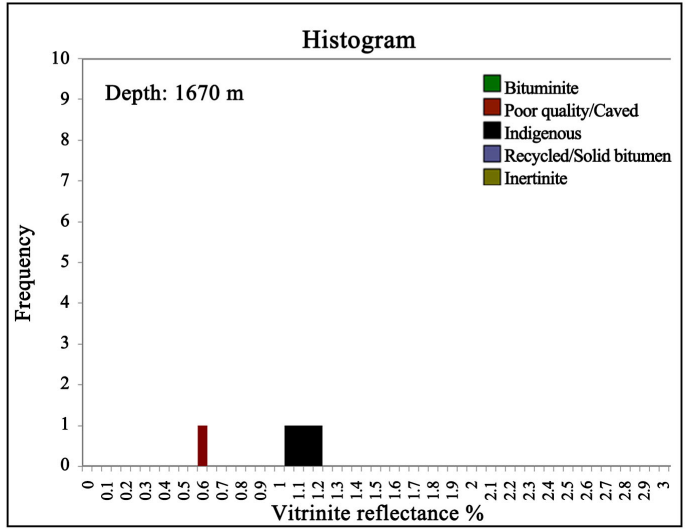

(f)

\begin{tabular}{|l|l|l|l|l|}
\hline $\begin{array}{l}\text { Depth } \\
(\mathrm{m})\end{array}$ & $\begin{array}{l}\text { Vitrinite } \\
\text { reflecta } \\
\text { nce } \\
\text { (\%Ro) }\end{array}$ & $\begin{array}{l}\text { Stand } \\
\text { ard } \\
\text { deviat } \\
\text { ion }\end{array}$ & $\begin{array}{l}\text { Cou } \\
\text { nt }\end{array}$ & $\begin{array}{l}\text { Confid } \\
\text { ence } \\
\text { (95\%) }\end{array}$ \\
\hline 1040 & 0.70 & 0.06 & 5 & 0.08 \\
\hline 1290 & 0.82 & 0.06 & 5 & 0.07 \\
\hline 1670 & 1.10 & 0.05 & 4 & 0.08 \\
\hline 2180 & 1.15 & 0.07 & 5 & 0.09 \\
\hline 2280 & 1.21 & 0.03 & 4 & 0.05 \\
\hline
\end{tabular}

(b)

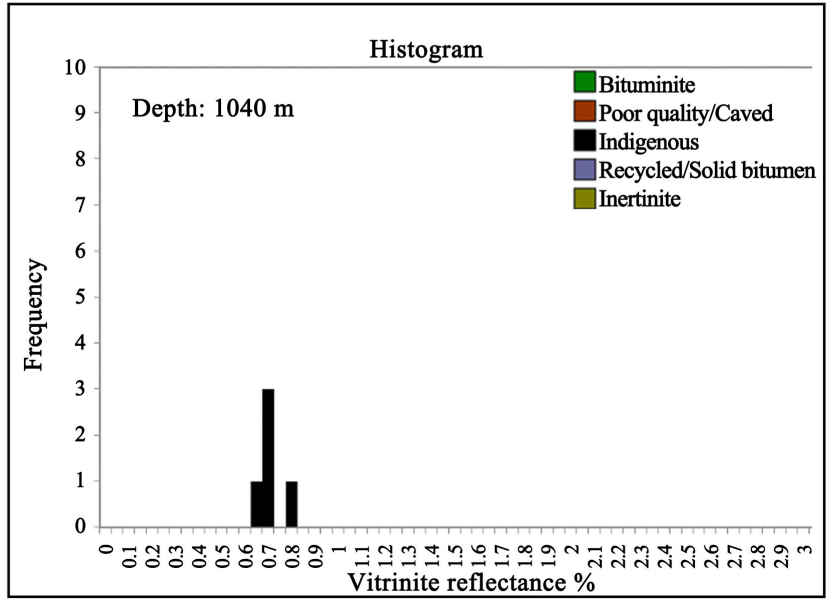

(c)

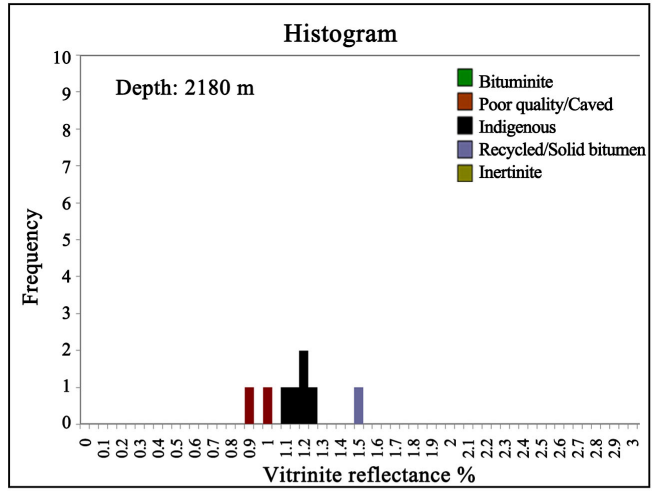

(e)

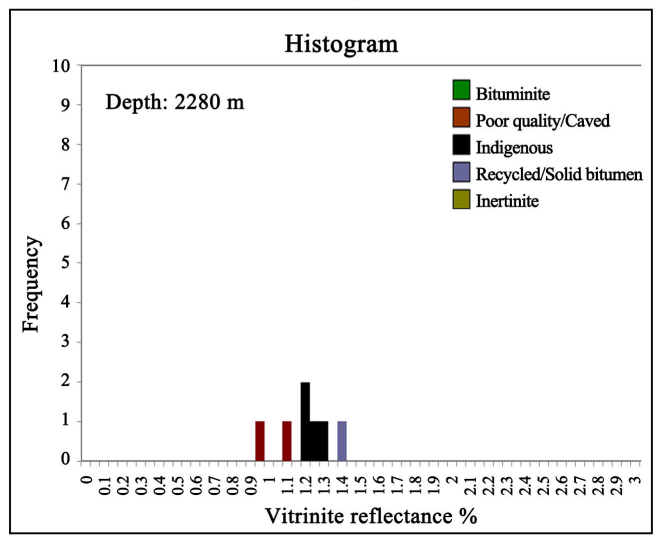

(g)

Figure 6. Organic matter type and level of maturation of Fika Shale as penetrated by Kinasar-1 well, SE Bornu Basin, Nigeria. (a) Depth/VR plot; (b) Table of VR Values; and (c) (d) (e) and (f) Histogram showing the type of the organic matter particles; (d) (e) (f) and (g) Histogram showing the type of the organic matter particles in Fika Formation as penetrated by Kinasar-1 well. 
reported from Gaibu-1 well [10]. From our [12] experience on the Bornu Basin the section within depth $2900 \mathrm{~m}$ to 4600 of Moumouni et al. [10] belongs to the Bima Formation. In fact, depth $2700 \mathrm{~m}$ to $2900 \mathrm{~m}$ falls within the Yolde/Gongila Formations that are deposited in a shallow marine environment. Gaibu well is another exploration well from south eastern portion of the basin having $10 \%$ of its tested samples yielding very good TOC results $(2.0 \%-5.7 \%)$ [11]. Similarly in Tuma well the TOC ranges between 0.69 and 1.89 within the depths 1000 and $3195 \mathrm{~m}$ [13]. Above $90 \%$ of the shaly section of Murshe-1 well has TOC above $0.6 \%$ required for hydrocarbon generation [13]. In Ziye-1 well also, above $80 \%$ of its analysed sample for TOC records value above $0.5 \mathrm{w} \%$ [15]. In terms of having sufficient organic matter for hydrocarbon generation in the south eastern portion of the Bornu Basin, there is no problem.

Another important parameter for source rock status assessment is the level of maturity of the organic matter, which could be determined by the pyrolysis temperature that corresponds to Pyrolysis oven temperature $\left(\mathrm{T}_{\max }\right)$ during maximum generation of hydrocarbons [1]. $\mathrm{T}_{\max }$ values greater than $435^{\circ} \mathrm{C}$ (minimum required for hydrocarbon generation [4] [6] are recorded for the section of Gaibu-1 well (Table 1(a)) of Moumouni et al. [10]) within the Fika Formation. Alalade and Tyson [11] examined two samples each for Tuma and Murshe wells and recorded values higher than $449^{\circ} \mathrm{C}$ Tmax. In this study only one of the samples examined has Tmax greater than $435^{\circ} \mathrm{C}$ (Table 1). These values suggest that the organic facies within the sampled intervals are thermally matured.

Another parameter for organic matter maturation level determination is the coloration index. Based on the modified Colouration index [1] [34] thermal alteration ratings of organic matter particles of yellow and orange to brownish yellow suggests associated hydrocarbon of oil to dry gas. Apart from the traces of liptinite found in some of the samples, algal cysts found fluoresced yellow with moderate intensity. One good quality spore fluoresced mid to dark orange with low intensity. Other tentatively identified algal cysts and spores were yellow orange and light orange, respectively. All these point to the possibility of finding liquid hydrocarbon apart from the already recorded gas within the area around Kinasar-1 well. The most reliable thermal measurement is the vitrinite reflectance. This study records above $0.6 \mathrm{w} \%$ minimum required value [1] for sediments that are predominantly type three as it is in Kinasar-1 (Figure 5).

Then the question is this: why are all the wells dry and only Kinasar-1 well produces only non-commercial gas? Evaluation of source rock potential is primarily based on appraisal of integrated multiple factors. Prominent among these factors is the hydrogen index, $\mathrm{HI}$, which is derived from the ratio of $\mathrm{CO}_{2}$ to TOC; and defined as $100 \times$ S3/TOC [34]. The HI is proportional to the amount of hydrogen contained within the kerogen. The value of HI provides information on the hydrocarbon product of sediments thus: between 50 and 200, gas; 200 to 300, Gas and oil; and above 300, oil [1]. In this study, the value of HI predomi- 
nantly falls within gas zone (Table 1). In addition, the plot of HI against Tmax suggest that only few beds within the tested Fika Formation could generate lean oil but gas based on the few data point that clusters within the boundary of oil/gas generation zone (Figure 5).

Generally, the level of the onset for oil generation delineated in this work is in fair agreement with the work of Nwakwo and Ekine [35] that the depth of oil ceiling in Kinasar 1 well lies at $1556 \mathrm{~m}$. The onset of oil generation however contradicts earlier submissions of Genik [20] who estimated the threshold of the "oil window" in the Bornu Basin to be at a depth of 2000 m. In Kinasar-1 this depth is below the intra-Maastrichtian unconformity.

\subsection{Implications of VR Reversal}

A critical look at the plot of VR against depth (Figure 4 and Figure 5) reveals a slight reversal in the depth trend of the VR value at about $2190 \mathrm{~m}$. Similar trends in the reversal of VR readings were observed in the data presented by [10] and [11] (Figure 7) in the wells that are very close to kinasar-1 well (Figure 2). This reversal suggests a significant change of the geothermal gradient resulting from either a change in the thermal conductivity of the strata or exhumation event. Uplift and erosion following the Santonian squeeze have been reported in the basin. From the stratigraphic position of the point of reversal reported herein the exhumation event lead to suspected unconformity occurring probably during the Middle Cretaceous but before the Santonian.

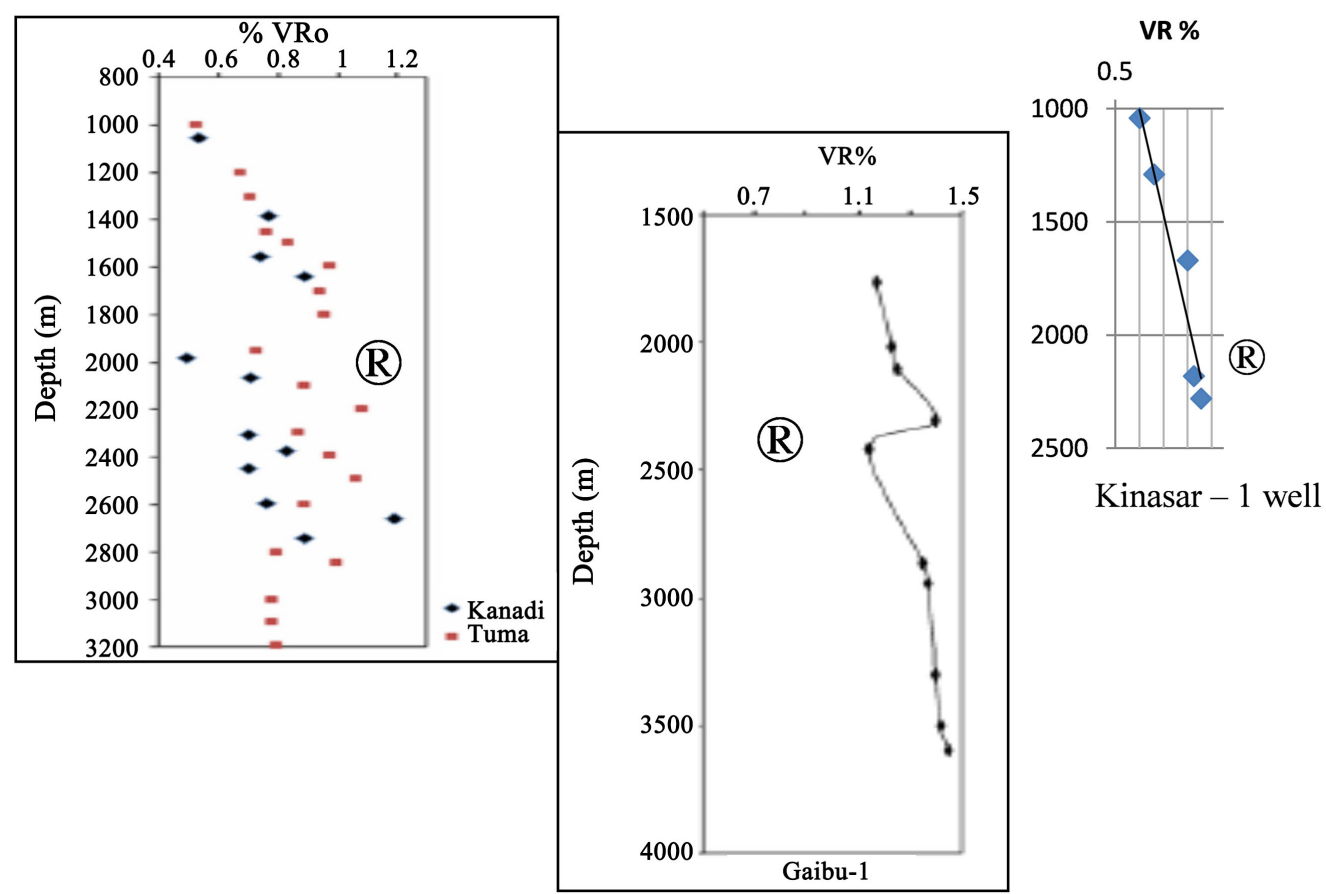

Figure 7. Vitrinite reflectance values obtained from the published works of Alalade and Tyson (2012) and Moumuni et al. (2007). Note the reversal ${ }^{\circledR}$ in the \% Ro values within a short range of depth in three selected wells from the SE portion (Figure 1) of the basin. The inferred cooling reflects exhumation that is totally different from the popular post Santonian squeeze in all the WCARS. 


\section{Conclusion}

The geochemical data obtained in this study revealed that, although the Bornu Basin is predominantly a potential gas prone basin, there are organic facies intervals that are oil prone within the basin. For example, by integrating data derived from four parameters of TOC, $\mathrm{T}_{\max }$, $\mathrm{HI}$ and Ro defined by Peters (1986) in Kinasar-1 well, several potential gas source and two potential oil source beds could be distinguished in the studied section of Fika Shale. All the samples analysed shows matured and even post matured strata within the Fika Shale. The area of study has not recorded economic oil discovery because nearly all the tested beds have low Hydrogen Index but holds high potential for gas accumulation. A further exploration of higher structure within the area of study both temporally and spatially is recommended. This is because hydrocarbon generation in the studied area could be presumed to start at a relatively shallow depth of $1090 \mathrm{~m}$.

\section{Acknowledgements}

The original research forming the source of the data used for this study was sponsored from the 2010 PTDF Research Competition funded by Petroleum Technology Development Fund (PTDF), Abuja, Nigeria. This is acknowledged with thanks. The authors are particularly grateful to Prof. R. W. Brown and Dr. K. Dobson of the University of Glasgow, UK for facilitating the geochemical analysis. Prof. C. M. Ekweozor's advice on how to go about the analysis is also appreciated. The initial draft of the paper was reviewed by Prof. J. A. Adekoya. I thank the anonymous reviewer and Joanna Cheng for editorial handling and helpful comments.

\section{Conflicts of Interest}

The authors declare no conflicts of interest regarding the publication of this paper.

\section{References}

[1] Mccarthy, K., Rojas, K., Niemann, M., Palmowski, D., Peters, K. and Stankiewicz, A. (2011) Basic Petroleum Geochemistry for Source Rock Evaluation. Oilfield Review, 23, 32-43.

[2] Dembicki, H.J. (2008) Three Common Source Rock Evaluation Errors Made by Geologists during Prospect or Play Appraisals. International Journal of Physical Sciences, 3, 152-155.

[3] Akande, W.G. (2012) Evaluation of Hydrocarbon Generation Potential of the Mesozoic Organic-Rich Rocks Using TOC Content and Rock-Eval Pyrolysis Techniques. Geosciences, 2, 164-169.

[4] Hunt, J.M. (1979) Petroleum Geochemistry and Geology. Freeman W. H., San Francisco.

[5] Tissot, B.P. and Welte, D.H. (1984) Petroleum Formation and Occurrence. Springer Verlag, New York. https://doi.org/10.1007/978-3-642-87813-8 
[6] Peters, K.E. (1986) Guidelines for Evaluating Petroleum Source Rock Using Programmed Analysis. The American Association of Petroleum Geologists Bulletin, 70, 318-329.

[7] Petters, S.W. and Ekweozor, C.M. (1982) Petroleum Geology of Benue Trough and Southeastern Chad Basin, Nigeria. American Association of Petroleum Geologists, 66, 1141-1149.

[8] Olugbemiro, R.O., Ligouis, B. and Abaa, S.I. (1997) The Cretaceous Series in the Chad Basin, NE Nigeria Source Rock Potential and Thermal Maturity. Journal of Petroleum Geology, 20, 51-58.

[9] Obaje, N.G., Wehner, H., Hamza, H., et al. (2004) New Geochemical Data from the Nigerian Sector of the Chad Basin: Implications on Hydrocarbon Prospectivity. Journal of African Earth Sciences, 38, 477-487. https://doi.org/10.1016/j.jafrearsci.2004.03.003

[10] Moumouni, A., Obaje, N.G., Nzegbuna, A.I., et al. (2007) Bulk Geochemical Parameters and Biomarker Characteristics of Organic Matter in Two Wells (Gaibu-1 and Kasade-1) from the Bornu Basin: Implications on the Hydrocarbon Potentials. Journal of Petroleum Sciences and Engineering, 58, 275-282. https://doi.org/10.1016/j.petrol.2007.01.004

[11] Alalade, A. and Tyson, R.V. (2010) Hydrocarbon Potential of the Late Cretaceous Gongila and Fika Formations, Bornu (Chad) Basin, NE Nigeria. Journal of Petroleum Geology, 33, 339-354. https://doi.org/10.1111/j.1747-5457.2010.00483.x

[12] Adekoya, J.A, Ola, P.S. and Olabode, S.O. (2014) Possible Bornu Basin Hydrocarbon Habitat-A Review. International Journal of Geosciences, 5, 983-996. https://doi.org/10.4236/ijg.2014.59084

[13] Alalade, B. (2016) Depositional Environments of Late Cretaceous Gongila and Fika formations, Chad (Bornu) Basin, Northeast Nigeria. Marine and Petroleum Geology, 75, 100-116.

[14] Olabode, S.O., Adekoya, J.A. and Ola, P.S. (2015) Distribution of Sedimentary Formations in the Bornu Basin, Nigeria. Petroleum Exploration and Development, 42, 674-682. https://doi.org/10.1016/S1876-3804(15)30062-8

[15] Obaje, N.G., Wehner, H., Scheeder, G., Abubakar, M.B. and Jauro, A. (2004) Hydrocarbon Prospectivity of Nigeria's Inland Basins: From the Viewpoint of Organic Geochemistry and Organic Petrology. AAPG Bulletin, 87, 325-353.

https://doi.org/10.1306/10210303022

[16] Guiraud, R. and Maurin, I. (1992) Early Cretaceous Rifts of Western and Central Africa: An Overview. Tectonophysics, 213, 153-168.

[17] Genik, G.J. (1993) Petroleum Geology of Cretaceous-Tertiary Rift Basins in Niger, Chad and Central African Republic. AAPG Bulletin, 77, 1405-1434.

[18] Brownfield, M.E., Schenk, C.J., Charpentier, R.F., Klett, T.R., Cook, T.A., Pollastro, R.M. and Tennyson, M.E. (2010) Assessment of Undiscovered Oil and Gas Resources of the Chad Basin Province, North-Central Africa U.S. Department of the Interior U.S. Geological Survey. Fact Sheet 2010-3096.

[19] Fairhead, J.D., Green, C.M. and Masterton, S.G. (2013) The Role That Tectonics, Inferred Stress Changes and Stratigraphic Unconformities Have on the Evolution of the West and Central African Rift System and the Atlantic Continental Margins. Tectonophysics, 59, 118-127. https://doi.org/10.1016/j.tecto.2013.03.021

[20] Raeburn and Jone (1934) The Chad Basin Geology and Water Supply Nigeria. Geological Survey Bulletin, 15, 61.

[21] Cratchley, C.R. (1960) Geophysical Survey of the South-Western Part of Chad Ba- 
sin. Unpublish Paper, C.C.T.T. Conference Geology, Kaduna.

[22] Carter, J.D., Barber, W., Tait, E.A., et al. (1963) The Geology of Parts of Adamawa, Bauchi and Borno Provinces in Northeastern Nigeria. Geological Survey of Nigeria Bulletin, 30, 1-108.

[23] Burke, K.C. (1976) The Chad Basin: An Active Intra-Continental Basin. Tectonophysics, 36, 197-206. https://doi.org/10.1016/0040-1951(76)90016-0

[24] Ayoola, E.O., Amechi, M. and Chukwe, R. (1981) Nigeria's Newer Exploration Provinces: Benue, Chad, Sokoto Basins. NMGS Conference.

[25] Avbovbo, A.A., Ayoola, E.O. and Osahon, G.A. (1986) Depositional and Structural Styles in the Chad Basin of Northeastern Nigeria. AAPG Bulletin, 70, 1787-1798.

[26] Fairhead, J.D. and Binks, R.M. (1991) Differential opening of the Central and South Atlantic Oceans and the Opening of the Central African Rift System. Tectonophysics, 187, 191-203. https://doi.org/10.1016/0040-1951(91)90419-S

[27] Genik, G.J. (1992) Regional Framework, Structural and Petroleum Aspects of Rift Basins in Niger, Chad and Central African Republic (C.A.R.). Tectonophysics, 213, 169-185. https://doi.org/10.1016/0040-1951(92)90257-7

[28] Zarboski, P., Ugodulunwa, F., Idornigie, A., Nnabo, P. and Ibe, K. (1997) Stratigraphy and Structure of the Cretaceous Gongola Basin, Northeast Nigeria. Bulletin du Centre de recherches Elf Exploration Production, 21, 153-178.

[29] Okosun, E.A. (1995) Review of the Geology of Bornu Basin. Journal of Mining and Geology, 31, 113-122.

[30] Hamza, H., Obaje, N.G. and Moumouni, A. (2011) Benthonic Foraminiferal Assemblages from the Bornu Basin, Northeastern Nigeria. Journal of Mining and Geology, 48, 91-115.

[31] Guiraud, R., Binks, R.M., Fairhead, J.D. and Wilson, M. (1992) Chronology and Geodynamic Setting of Cretaceous-Cenozoic Rifting in West and Central Africa Tectonophysics, 213, 227-234.

[32] Furon, R. (1963) Geology of Africa. Oliver and Boyd, Edwin and London.

[33] Adegoke, O.S., Agumanu, A.E., Benkhelil, M.J. and Ajayi, P.O. (1986) New Stratigraphic, Sedimentologic and Structural Data on the Kerri-Kerri Formation, Bauchi and Borno States, Nigeria. Journal of African Earth Sciences, 5, 249-277.

[34] Staplin, F.L. (1969) Sedimentary Organic Matter, Organic Metamorphism, and Oil and Gas Occurrences. Bulletin of Canadian Petroleum Geology, 17, 47-66.

[35] Nwankwo, C.N. and Anthony, S.E. (2009) Geothermal Gradients in the Chad Basin, Nigeria, from Bottom Hole Temperature Logs. International Journal of Physical Sciences, 4, 777-783. 